\title{
Antihypoxic activities of Crataegus pentaegyn and Crataegus microphylla fruits-an in vivo assay
}

\author{
Mohammad Ali Ebrahimzadeh ${ }^{1}$, Masoumeh Khalili", Negar Jafari ${ }^{1}$, Giti Zareh ${ }^{1}$, \\ Davood Farzin 3 , Gholamreza Amin ${ }^{4}$
}

\begin{abstract}
${ }^{1}$ Pharmaceutical Sciences Research Center, School of Pharmacy, Mazandaran University of Medical Sciences, Sari, Iran, ${ }^{2}$ Neuroscience Research Center, Golestan University of Medical Sciences, Gorgan, Iran. ${ }^{3}$ Department of Pharmacology, School of Medicine, Mazandaran University of Medical Sciences, Sari, Iran, ${ }^{4}$ Department of Pharmacognosy, Faculty of Pharmacy,

Tehran University of Medical Sciences, Tehran, Iran
\end{abstract}

\begin{abstract}
The aim of this study was to evaluate anti-hypoxia activity of polyphenolic extracts of Crataegus microphylla and Crataegus pentaegyn on mice. Three experimental models of hypoxia were considered, including asphyctic hypoxia, haemic hypoxia, and circulatory hypoxia. Polyphenolic extract of both plants exhibited significant anti-hypoxic activity and prolonged animal survival time. Anti-hypoia activity of C. pentaegyn was found to be superior to that of C. microphylla in circulatory and asphyctic hypoxia. Antihypoxic activity of these extracts may be attributed to their phenolic compounds.
\end{abstract}

Keywords: Crataegus pentaegyna. Crataegus microphylla. Antihypoxia/evaluation. Circulatory hypoxia.

\section{INTRODUCTION}

Hypoxia, a state of oxygen deficiency, occurs in a number of human diseases, including heart diseases, ischemia, bleeding and heart attack. Hypoxia causes several deleterious effects, which finally may lead to tissue destruction and death (Kiang, Tsen, 2006). Hypoxia mediates the production of nitric oxide, which in turn provokes lipid peroxidation and cell membrane injury (Kiang, Tsen, 2006). Hence, nitric oxide scavenging may neutralize hypoxia. Hypoxia can induce ROS(reactive oxygen species) production, as well (Armstrong, 2010).

Antioxidants have been proven to scavenge ROS and therefore are able to exhibit antihypoxia property. Plants are considered as a valuable source of natural antioxidants. Hawthorn [Crataegus spp. (Rosaceae)] is one of the oldest medicinal plants that is widely used throughout the world, especially in South European countries and Turkey (Bahorun et al., 2003, Barros, Carvalho, Ferreira, 2011). Crataegus spp. is mainly used for treatment of cardiovascular diseases (Rigelsky and

\footnotetext{
*Correspondence: M. Khalili.Neuroscience Research Center,Golestan University of Medical Sciences, Gorgan, Iran. Tel: +981732422644 / Fax: +981732420515. E-mail:mkhalili_ps@yahoo.com/mkhalili_phs@goums.ac.ir
}

Sweet, 2002).Two Crataegus species grow in northern provinces of Iran, C. pentaegyna (CP) and C. microphylla (CM) (Ebrahimzadeh, Bahramian, 2009). Crataegus extract contain flavonoid and phenolic compounds that exhibit antioxidant activity (Hertog et al., 1993, Zhang et al., 2001). Crataegus may have cardio protective properties (Chatterjee et al., 1997). Antioxidant activity of hawthorn species has already been reported (Bahorun et al., 1994, Ljubuncic et al., 2005). Hawthorn contains different phenolic and flavonoids compounds, including: chlorogenic acid, epicatechin, rutin, hyperoside and vitexin (Zhang et al., 2001). Previous studies show that hawthorn has high polyphenolic and flavonoids compunds (Rabiei et al., 2012). The aim of the present work was to determine the antihypoxic activities of polyphenol fraction of C. pentaegyna and C. microphylla fruits.

\section{MATERIAL AND METHODS}

\section{Plant material and preparation of phenolic fractions}

C. pentaegyna Sub sp. Elburensis (CP) and C. microphylla $(\mathrm{CM})$ fruits were collected from Mazandaran forests in autumn 2012, dried at room temperature, and 
subjected to polyphenol extraction as descried previously (Rabiei et al., 2012). Extraction was performed two times at $20^{\circ} \mathrm{C}$ in a shaking incubator. Extracting time was 30 min, and extracting solvent was $100 \mathrm{~mL}$ of methanol/ acetone/water (3.5/3.5/3) containing $1 \%$ formic acid. The extracts were combined and filtered through two layers of cheesecloth. The collected filtrate was centrifuged at $7000 \mathrm{~g}$ for $15 \mathrm{~min}$. The supernatant was collected and then evaporated under vacuum at $35-40{ }^{\circ} \mathrm{C}$ to remove methanol and acetone. Lipophilic pigments were then eliminated from the aqueous phase by two successive extractions in a separation funnel with a twofold volume of petroleum ether. The aqueous phase was collected and further extracted three times using equal volume of ethyl acetate in the separation funnel. Three ethyl acetate phases were collected and concentrated over a rotary vacuum until obtaining a crude solid extract, which then was freezedried for complete solvent removal.

\section{Determination of total phenolic and flavonoid contents}

Total phenolic content was measured calorimetrically using the Folin-Ciocalteau assay (Rabiei et al., 2012). The concentration of total phenolic compounds in the plant extracts was expressed as mg of gallic acid equivalents (GAE) per gram of extract using the equation obtained from standard gallic acid graph: Absorbance $=0.0054 \mathrm{x}$ total phenols [mg gallic acid] $+0.0628\left(\mathrm{R}^{2}=0.987\right)$. The total flavonoid content was determined using aluminum chloride method (Ebrahimzadeh et al., 2010). The total flavonoid content in the extracts was expressed as $\mathrm{mg}$ of quercetin equivalents $(\mathrm{QE})$ per gram of extract using the equation obtained from standard quercetin graph: Absorbance $=0.0063 \mathrm{x}$ total flavonoids [mg quercetin] $\left(\mathrm{R}^{2}=0.999\right)$.

\section{Assay of nitric oxide-scavenging activity}

For the experiment, sodium nitroprusside (concentration of $10 \mathrm{mM}$, prepared in phosphate-buffered saline) was mixed with different concentrations of each extract, and incubated at room temperature. After 150 min, $0.5 \mathrm{~mL}$ of Griess reagent was added and absorbance was measured at $546 \mathrm{~nm}$. Quercetin was used as a positive control (Ebrahimzadeh et al., 2013).

\section{HPLC analysis}

The phenolic compounds present in the $\mathrm{CM}$ and $\mathrm{CP}$ fruits were analyzed using HPLC method, as described previously (Zhang et al., 2001). The HPLC system consisted of a model K-1001 solvent delivery system equipped with a Rheodyne injection valve ( $20 \mu 1$ sample loop inserted) and a UV-vis spectrophotometric detector model K-2600 set at $278 \mathrm{~nm}$ (all from Knauer Assoc., Germany). The analysis was performed using an ODS-C18 column $(250 \mathrm{~mm} \times 4.6 \mathrm{~mm}$ I.D., $5 \mathrm{~m}$ particle size, Shimpack VP-ODS). The mobile phase was $20 \%$ acetonitrile in $25 \mathrm{mM}$ sodium phosphate buffer $(\mathrm{pH}=3)$. The mobile phase flow rate was $1.0 \mathrm{~mL} / \mathrm{min}$ and all the measurements were done at ambient temperature.

\section{Animals}

Male Swiss albino mice $(20 \pm 2 \mathrm{~g})$ were randomLy housed in groups of 10 in polypropylene cages at an ambient temperature $\left(25 \pm 1{ }^{\circ} \mathrm{C}\right.$ and $45-55 \%$ relative humidity) with a $12 \mathrm{~h}$ light: $12 \mathrm{~h}$ dark cycle (lights on at 7 a.m.). The animals had free access to standard pellet and water and libitum. Experiments were conducted between 8:00 and 14:00 o'clock. All the experimental procedures were conducted in accordance with the NIH guidelines of the Laboratory Animal Care and Use. The Institutional Animal Ethical Committee (IAEC) of Mazandaran University of Medical Sciences also approved the experimental protocol (Approval no: 1211, 2013).

\section{Determination of the maximum non-fatal dose}

Each extract was injected $(2 \mathrm{~g} / \mathrm{kg})$ to the separated groups (each group contained four mice) to determine the maximum non-fatal dose. After $48 \mathrm{~h}$, the induction of any mortality was considered as the maximum non-fatal dose (Ebrahimzadeh et al., 2010).

\section{Anti-hypoxic activity}

Asphyctic Hypoxia: To induce hypoxia, animals were separately put in a tightly closed $300 \mathrm{~mL}$ glass container and then submerged in water (an aquarium filled with water, temperature of $25^{\circ} \mathrm{C}$ ) in. The animals died from hypoxia after approximately 2 min convulsions. The latencies for death were recorded. $30 \mathrm{~min}$ before being subjected to hypoxia, mice were injected with 200 or 400 $\mathrm{mg} / \mathrm{kg}$ of extracts. Two control group were considered, one received with phenytoin $(50 \mathrm{mg} / \mathrm{kg})$ and the other received normal saline (Eslami et al., 2011).

\section{Haemic hypoxia}

The effect of the extracts in preventing haemic 
Hypoxia was evaluated as described previously (Ebrahimzadeh et al., 2010, Nabavi et al., 2011). Summarily, forty mice were divided into five groups, each consisting of eight mice. Control group was treated with normal saline. After being injected with 200 or $400 \mathrm{mg} /$ $\mathrm{kg}$ of extracts, the mice (thirty mice) received $360 \mathrm{mg} / \mathrm{kg}$ $\mathrm{NaNO}_{2}$. The animal survival time was recorded.

\section{Circulatory hypoxia}

The effect of the extracts in preventing circulatory Hypoxia was evaluated as described previously (Ebrahimzadeh et al., 2010, Nabavi et al., 2011). Summarily, forty mice were divided into 5 groups of 8 . The control group received normal saline. Thirty minutes after being injected with 50 or $100 \mathrm{mg} / \mathrm{kg}$ of the extracts, the mice received $150 \mathrm{mg} / \mathrm{kg} \mathrm{NaF}$ (as i.p. adminstration). The animal survival time was recorded.

\section{Statistical analysis}

All the experimental results were centered using three parallel measurements of the mean $\pm \mathrm{SD}$. Analysis of variance (ANOVA) was performed. Mean comparison was carried out using Duncan's new multiple-range test. All $p$ values less than 0.05 were regarded to be significant. $\mathrm{The} \mathrm{IC}_{50}$ values were calculated from linear regression analysis.

\section{RESULTS AND DISCUSSION}

\section{Total phenolic content}

Antioxidant activity of herbal extracts has been attributed to the presence of phenolic compounds (Ebrahimzadeh et al., 2008). The total phenolic content of polyphenol fraction in CM $\left(1136.0 \pm 29.5 \mathrm{GAE} \mathrm{mg} \mathrm{g}^{-1}\right.$ of extract) is greater than that in CP $(721.1 \pm 14.7 \mathrm{GAE}$ $\mathrm{mg} \mathrm{g}^{-1}$ of extract). Previous studies with different herbal extract show that there is a significant relationship between the antioxidant activity and total phenolic contents (Ebrahimzadeh et al., 2008). Therefore, PP fraction may be regarded as a valuable source of natural antioxidant for treating free radical-mediated human diseases. (Khalili et al., 2015).

\section{Total flavonoid content}

Flavonoids are a family of polyphenolic compounds that are found in different plant species. Flavonoids are responsible for the color of fruits and flowers (Cook,
Samman, 1996). These compounds are secondary metabolites that have gained enormous attention in pharmaceutical and food industries, mainly due to their antioxidant activity (Ebrahimzadeh et al., 2008). Some flavonoids can react with $\mathrm{Al}^{3+}$ and form a red complex with absorbance wavelength of $510 \mathrm{~nm}$. The total flavonoid content of CP and CM was calculated to be $87.92 \pm 2.6$ $\mathrm{QE} \mathrm{mg} \mathrm{g}{ }^{-1}$ and $6.25 \pm 0.1 \mathrm{QE} \mathrm{mg} \mathrm{g}^{-1} \mathrm{CM}$, respectively. Flavonoids may be useful for treating atherosclerosis and cardiovascular diseases through ROS scavenging activity (Hertog et al., 1993).

\section{HPLC analysis}

Hawthorn contains numerous phenolic and flavonoids compounds, including chlorogenic acid, epicatechin, rutin, hyperoside and vitexin (Zhang et al., 2001). An isocratic elution of acetonitrile in sodium phosphate buffer $(20: 80)(\mathrm{pH}=3)$ was used to achieve complete separation. Typical retention times for chlorogenic acid and rutin were $3.78 \mathrm{~min}$ and $6.26 \mathrm{~min}$, respectively. The comparison of retention times with that of the standards identified the peaks of the analytes in the hawthorn extracts. The chlorogenic acid and rutin contents for $C$. pentaegyna fruit were 91.66 and $15.99 \mathrm{mg} \mathrm{g}^{-1}$ of extract, respectively. These contents for C.microphylla fruit were 119.31 and $84.65 \mathrm{mg} \mathrm{g}^{-1}$ of extract, respectively.

The HPLC analysis revealed that hawthorn fruit contains different phenolic compounds, e.g. chlorogenic acid (a phenolic acid) and rutin (a flavonoid). These compounds have many biological activities. Chlorogenic acid is one of the most abundant phenols in human diet whose antioxidant activity has been well demonstrated. Chlorogenic acid has been reported to scavenge $\mathrm{OH}$ free radicals in a dose-dependent manner (Zhang et al., 2003). ROS causes oxidative stress in neural cells through hydrogen peroxide production (Pavlica and Gebhardt, 2005). Chlorogenic acid has been reported to suppress ROS-mediated activation of NF- $\kappa \mathrm{B}$ (nuclear factor kappa-light-chain-enhancer of activated $\mathrm{B}$ cells) and AP-1 (Activator protein 1). NF- $\kappa \mathrm{B}$ and AP-1 are two eukaryotic transcription factor that are involved in many human cancers (Feng et al., 2005).

\section{Nitric oxide-scavenging activity}

Extracts showed moderate nitric oxide-scavenging activity. The $\mathrm{CM}$ extract was found to be more active than $\mathrm{CP}\left(\mathrm{IC}_{50}=225 \pm 9\right.$ and $797 \pm 21 \mu \mathrm{g} \mathrm{mL}^{-1}$, respectively $)$. Quercetin, the control, was more potent than both extracts $\left(\mathrm{IC}_{50}=155.0 \pm 6.4 \mu \mathrm{g} \mathrm{mL}^{-1}\right)$. 
TABLE I - Antihypoxic activities of C. pentaegyna and C. microphylla in haemic and circulatory hypoxia in mice

\begin{tabular}{|c|c|c|c|c|}
\hline Groups & Dose (mg/kg) & $\begin{array}{l}\text { Haemic hypoxia activity } \\
\text { (min) }\end{array}$ & Dose (mg/kg) & $\begin{array}{c}\text { Circulatory hypoxia } \\
\text { activity (min) }\end{array}$ \\
\hline Control & -- & $7.24 \pm 0.94$ & -- & $9.29 \pm 0.95$ \\
\hline \multirow{2}{*}{ C. pentaegyna } & 200 & $6.46 \pm 0.46^{\mathrm{ns}}$ & 50 & $19.24 \pm 2.14 * *$ \\
\hline & 400 & $7.94 \pm 0.67^{\mathrm{ns}}$ & 100 & $38.67 \pm 9.81 * * *$ \\
\hline \multirow{2}{*}{ C. microphylla } & 200 & $7.33 \pm 0.52^{\mathrm{ns}}$ & 50 & $22.43 \pm 3.34 * *$ \\
\hline & 400 & $8.43 \pm 1.40^{*}$ & 100 & $26.44 \pm 8.32 * * *$ \\
\hline
\end{tabular}

${ }^{a}$ Data are expressed as mean $\pm S D(n=8),\left({ }^{*} \mathrm{P}<0.05, * * \mathrm{P}<0.01,{ }^{* * *} \mathrm{P}<0.001\right.$, compared to control $)$

\section{The maximum non-fatal doses}

The maximum non-fatal doses for extracts were at least $2 \mathrm{~g} / \mathrm{kg}$. No mortality was observed at this dose after $48 \mathrm{~h}$.

\section{Antihypoxic activities}

The extracts postponed hypoxia in a dose-dependent manner. CP (at $100 \mathrm{mg} / \mathrm{kg}$ ) was found to be the most effective extract against circulatory hypoxia. CM (at 100 $\mathrm{mg} / \mathrm{kg}$ ) kept mice alive for $26.44 \pm 8.32 \mathrm{~min}$ (Table I). Administration of sodium fluoride, a circulatory hypoxia inducing agent, increases the blood histamine content and decreases the oxygen carrying capacity (Khalili et al., 2015). Chemical hypoxia is induced by the injection of $\mathrm{NaNO}_{2}$, which reduces blood oxygen-carrying capacity by converting hemoglobin to methemoglobin (Khalili et al., 2015). We found that CM (at $400 \mathrm{mg} / \mathrm{kg}$ ) was the most effective extract in preventing haemic hypoxia, which kept the mice alive for $8.43 \pm 1.40 \mathrm{~min}$. Compared to the control group, CM prolonged survival time significantly. $\mathrm{CP}$ at $400 \mathrm{mg} / \mathrm{kg}$ prolonged survival time to $7.94 \pm 0.67$, which found to be insignificant when compared to the control group (Table I).

The extracts showed no activity in asphytic model (Table I). Compared to the control group, in which the mice died of hypoxia in $28.47 \pm 3.38 \mathrm{~min}$, the mice receiving 400 $\mathrm{mg} / \mathrm{kg}$ of CM died of hypoxia after $23.76 \pm 3.51 \mathrm{~min}$.

Studies regarding anti-hypoxic activity of hawthorn are limit. The effects of hawthorn extract on thrombus formation and on hypoxia-treated human umbilical vein endothelial cell are examples of these studies (Lan et al., 2005). Lan and colleagues (2005) showed that hawthorn extract (concentrations of 5 and $10 \mu \mathrm{g} \mathrm{mL}^{-1}$ ) decreases the negative of hypoxia in cells by regulating $\mathrm{NO}$ and calcium ion levels (Lan et al., 2005). The results of our study are consistent with the results of previous studies in which flavonoids are reported to have antihypoxic activity
(Hertog et al., 1993, He et al., 2010). (Ebrahimzadeh et al., 2008).

\section{CONCLUSION}

Polyphenolic extracts of Crataegus pentaegyna and Crataegus microphylla can be regarded as a valuable source for natural compounds with anti-hypoxic activity. The extracts postpone circulatory hypoxia in a dose dependent manner.

\section{REFERENCES}

Armstrong D. Advanced protocols in oxidative stress. II II. New York: Humana Press; 2010.

Bahorun T, Aumjaud E, Ramphul H, Rycha M, LuximonRamma A, Trotin F, Aruoma OI. Phenolic constituents and antioxidant capacities of Crataegus monogyna (Hawthorn) callus extracts. Food/Nahrung. 2003;47(3):191-98.

Bahorun T, Gressier B, Trotin F, Brunet C, Dine T, Luyckx M, et al. Pinkas M. Oxygen species scavenging activity of phenolic extracts from hawthorn fresh plant organs and pharmaceutical preparations. Arzneimittel-Forschung. 1996;46(11):1086-89.

Bahorun T, Trotin F, Pommery J, Vasseur J,Pinkas M. Antioxidant activities of Crataegus monogyna extracts. Planta Med. 1994;60(4):323-8.

Barros L, Carvalho AM, Ferreira I C. Comparing the composition and bioactivity of Crataegus monogyna flowers and fruits used in folk medicine. Phytochem Anal. 2011;22(2):181-88.

Chatterjee S, Koch E, Jaggy H, Krzeminski T. In vitro and in vivo studies on the cardioprotective action of oligomeric procyanidins in a Crataegus extract of leaves and blooms. Arzneimittel-Forschung. 1997;47(7):821-25. 
Cook N, Samman S. Flavonoids-chemistry, metabolism, cardioprotective effects, and dietary sources. J Nutr Biochem. 1996;7(2):66-76.

Ebrahimzadeh M, Bahramian F. Antioxidant activity of Crataegus pentaegyna subsp. elburensis fruits extracts used in traditional medicine in Iran. Pak J Biol Sci. 2009;12(5):413.

Ebrahimzadeh M, Nabavi S, Nabavi S, Pourmorad F. Nitric oxide radical scavenging potential of some Elburz medicinal plants. Afr J Biotechnol. 2013;9(32):5212-17.

Ebrahimzadeh MA, Nabavi SF, Nabavi SM, Eslami B. Antihypoxic and antioxidant activity of Hibiscus esculentus seeds. Grasas y aceites. 2010;61(1):30-36.

Ebrahimzadeh MA, Pourmorad F, Bekhradnia AR. Iron chelating activity, phenol and flavonoid content of some medicinal plants from Iran. Afr J Biotechnol. 2008;7(18):3188-92.

Eslami B, Nabavi S, Nabavi S, Ebrahimzadeh M, Mahmoudi M. Pharmacological activities of Hypericum scabrum L. Eur Rev Med Pharmacol Sci. 2011;15(5):32-37.

Feng R, Lu Y, Bowman LL, Qian Y, Castranova V, Ding M. Inhibition of activator protein-1, NF- $\kappa \mathrm{B}$, and MAPKs and induction of phase 2 detoxifying enzyme activity by chlorogenic acid. J Biol Chem. 2005;280(30):27888-95.

He C, Ji X, Pan Y, Wang H, Wang K, Liang M, Yang L. Antioxidant activity of alcoholic extract of Agrimonia pilosa Ledeb. Med Chem Res. 2010;19(5):448-461.

Hertog MG, Feskens EJ, Kromhout D, Hertog M, Hollman P, Hertog M, Katan M. Dietary antioxidant flavonoids and risk of coronary heart disease: the Zutphen Elderly Study Lancet. 1993;342(8878):1007-11.

Khalili M, Dehdar T, Hamedi F, Ebrahimzadeh M, Karami M. Antihypoxic activities of Eryngium caucasicum. Eur Rev Med Pharmacol Sci. 2015;19(17):3282-5.
Kiang JG,Tsen K. Biology of hypoxia. Chin J Physiol. 2006;49(5):223.

Lan W-J, Ge Y-K, Zheng X-X. Regulative effects of hawthorn leave flavonoids on cytotoxicity, $\mathrm{NO}$ and $\mathrm{Ca} 2+$ in hypoxiatreated human umbilical vein endothelial cells. Hang tian yi xue yu yi xue gong cheng. Space Med Med Eng. 2005;18(3):157-60.

Ljubuncic P, Portnaya I, Cogan U, Azaizeh H, Bomzon A. Antioxidant activity of Crataegus aronia aqueous extract used in traditional Arab medicine in Israel. J ethnopharmacol. 2005;101(1):153-61.

Nabavi SF, Ebrahimzadeh MA, Nabavi SM, Mahmoudi M, Rad SK. Biological activities of Juglans regia flowers. Rev Bras Farmacogn. 2011;21(3):465-70.

Pavlica S, Gebhardt R. Protective effects of ellagic and chlorogenic acids against oxidative stress in PC12 cells. Free Radic Res. 2005;39(12):1377-90.

Rabiei K, Bekhradnia S, Nabavi S, Nabavi S, Ebrahimzadeh M. Antioxidant activity of polyphenol and ultrasonic extracts from fruits of Crataegus pentagyna subsp. elburensis. Nat Prod Res. 2012;26(24):2353-57.

Rigelsky JM, Sweet BV. Hawthorn: pharmacology and therapeutic uses. Am J Health Syst Pharm. 2002;59(5):417-22.

Zhang L-Y, Cosma G, Gardner H, Vallyathan V, Castranova V. Effect of chlorogenic acid on hydroxyl radical. Mol Cell Biochem. 2003;247(1-2):205-10.

Zhang Z, Chang Q, Zhu M, Huang Y, Ho WK, Chen Z-Y. Characterization of antioxidants present in hawthorn fruits. $\mathrm{J}$ Nutr Biochem. 2001;12(3):144-52.

Received for publication on $21^{\text {st }}$ June 2017 Accepted for publication on 22 $2^{\text {nd }}$ November 2017 